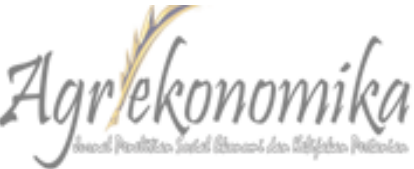 \\ Jurnal Sosial Ekonomi dan Kebijakan Pertanian
}

http://journal.trunojoyo.ac.id/agriekonomila

Agriekonomika Volume 6, Nomor 1, 2017

\section{KARAKTERISTIK DAN PERSEPSI MASYARAKAT DESA WONOASRI, KECAMATAN TEMPUREJO, KABUPATEN JEMBER TERHADAP KEGIATAN PEMULIHAN EKOSISTEM TAMAN NASIONAL MERU BETIRI}

\author{
$\triangle$ Dodit Ari Guntoro \\ Balai Taman Nasional Meru Betiri
}

\begin{abstract}
Received: 07 November 2016; Accepted: 12 April 2017; Published: 17 April 2017
DOI: http://dx.doi.org/10.21107/agriekonomika.v6i1.1974
\end{abstract}

\begin{abstract}
ABSTRAK
Pemulihan Ekosistem di Taman Nasional Meru Betiri (TNMB) dilakukan sebagai upaya untuk mencapai suatu kondisi masa depan tertentu sesuai dengan tujuan pengelolaan. Penelitian ini bertujuan untuk mengetahui karakteristik dan persepsi masyarakat desa Wonoasri terhadap kegiatan Pemulihan Ekosistem. Metode yang digunakan dalam penelitian ini adalah metode deskriptif. Teknik pengambilan sampel dilakukan secara acak terhadap 34 petani yang tergabung dalam Kelompok Tani Mitra Rehabilitasi (KETANMERAH). Data selanjutnya dianalisa menggunakan pendekatan skala Likert. Hasil penelitian menunjukkan bahwa karakteristik masyarakat desa Wonoasri berusia produktif dan rata-rata telah berpartisipasi selama 13 tahun. Persepsi petani KETANMERAH terkait pengetahuan Pemulihan Ekosistem dan kesediaan melakukan pembibitan mandiri memiliki nilai tinggi dikarenakan Program Rehabilitasi di TNMB telah berjalan sejak tahun 1999. Persepsi terkait jumlah tanaman pokok yang dipersyaratkan dan kesediaan meninggalkan lahan rehabilitasi memiliki nilai sedang. Hal ini terkait jumlah dan jenis tanaman pokok petani yang belum sesuai Kesepakatan serta ketergantungan yang tinggi terhadap lahan rehabilitasi.
\end{abstract}

Kata Kunci: Agroforestri, Daerah Penyangga, Petani Rehabilitasi, Tanaman Pokok

\section{CHARACTERISTIC AND PERCEPTION OF WONOASRI COMMUNITY TEMPUREJO DISTRICT JEMBER ON ACTIVITIES OF ECOSYTEM RECOVERY IN MERU BETIRI NATIONAL PARK}

\begin{abstract}
Ecosystem recoveryin Meru Betiri National Park (TNMB) was conducted to reach a certain condition as it listed in the objective of management. This research was conducted to evaluate the characteristic and perception of Wonoasri communityon the activities of ecocystem recovery. This reseach method was descriptive. Data were randomly collected on thirtyfour (34) respondens member of KelompokTani Mitra Rehabilitasi (KETANMERAH). Data were then analyzed with Likert scale. The results showed that charateristic of Wonoasri community involved in therecovery activities were in productive age. The average of their participations in those activities was around 13 years. Perception of those farmers on knowledge of ecosystem recovery was high as the rehabilitation program in TNMB have been conducted since 1999. Perception on the number of major plants and willingness to leave the rehabilitation area was moderate. The species and total amount of major plants was not appropriate according the agreement with $T N M B$ as well as there was a high dependency of farmers on the rehabilitation area.
\end{abstract}

Keyword: Agroforestry, Buffer Zones, Rehabilitation Farmers, Main Plants

\footnotetext{
Corresponding author:

Address : Jl. Sriwijaya No.53, Kranjingan, Sumbersari, Kabupaten Jember

Email : dodit.tnmb@gmail.com

Phone : 08123356575
} 


\section{PENDAHULUAN}

Berdasarkan Review Zonasi Balai Taman Nasional Meru Betiri (TNMB) yang disahkan oleh Direktur Jenderal Perlindungan Hutan dan Konservasi Alam (PHKA) Nomor: SK.101/IV-SET/2011 Tanggal 20 Mei 2011 tentang Zonasi Taman Nasional Meru Betiri menyebutkan bahwa Balai Taman Nasional Meru Betiri memiliki zona rehabilitasi seluas $2.733,5 \mathrm{Ha}$. Zona rehabilitasi ini muncul sebagai akibat adanya euphoria masyarakat di awal Reformasi di tahun 1998 yang bersama-sama melakukan penjarahan hutan jati TNMB seluas 4.000 Ha.Kawasan hutan jati ini merupakan perluasan kawasan TNMB dari Perhutani, berdasarkan SK Menteri Pertanian No. 529/Kpts/Um/7/1982 tanggal 21 Juni 1982. Tanaman Jati ini dulunya ditanam pada tahun 1967/1968 dengan sistem tumpangsari kerjasama antara Perum Perhutani dengan masyarakat (Amzu, 2007).

Sebagai upaya mengembalikan fungsi hutan TNMB maka dilakukan kegiatan rehabilitasi yang melibatkan masyarakat melalui sistem kemitraan dengan membentuk Kelompok Tani Mitra Rehabilitasi (KETANMERAH). Masyarakat melakukan penanaman tanaman pokok secara swadaya dengan kompensasi dapat menanam tanaman semusim/tumpasari sambil menunggu tanaman pokok berbuah. Dalam kemitraan dengan KETANMERAH ini juga telah diatur jenis-jenis tanaman pokok dan tanaman semusim yang boleh ditanam yang tertuang dalam Kesepakatan Kerjasama Pengelolaan Kawasan di Zona Rehabilitasi Taman Nasional Meru Betiri (Meru Betiri, 2007). Selanjutnya pada periode 2010-2015, kegiatan rehabilitasi di TNMB dilakukan melalui skema RHL dengan sumber dana dari UPT Balai Pengelolaan Daerah Aliran Sungai (BPDAS) Sampean, Bondowoso.

Mulai tahun 2015, rehabilitasi skema RHL di Taman Nasional berubah menjadi mekanisme Pemulihan ekosistem dengan tujuan dikembalikan ke ekosistem semula atau kondisi masa depan tertentu sesuai dengan tujuan pengelolaan. Kegiatan Pemulihan ekosistem juga menjadi salah satu indikator kinerja kegiatan (IKK) dari Direktur Kawasan Konservasi, Ditjen KSDAE 2015-2019 dimana ditargetkan 100.000 Ha dapat dipulihkan kondisi ekosistemnya dengan lokasi prioritas pada zona/blok rehabilitasi UPT TN/KSDA.

Balai Taman Nasional Meru Betiri merupakan 1 dari 37 Taman Nasional yang akan dipulihkan ekosistemnya selama 5 tahun ke depan. Target pemulihan ekosistem di Balai TN. Meru Betiri adalah sebesar $1.000 \mathrm{Ha}$.Salah satu target lokasi kegiatan Pemulihan Ekosistem TNMB adalah Resort Wonoasri seluas $290 \mathrm{Ha}$. Salah satu faktor yang mempengaruhi keberhasilan kegiatan Pemulihan Ekosistem dengan pola partisipasif ini adalah petani mitra rehabilitasi. Berdasarkan pengamatan langsung di lapangan diketahui bahwa kegiatan pemulihan ekosistem di TNMB termasuk dalam praktek Agroforestri sederhana. Sistem agroforestri sederhana merupakan sistem pertanian dimana pepohonan di tanam secara tumpangsari dengan satu atau lebih jenis tanaman semusim (Foresta \& Michon, 1997).

Adanya kegiatan Pemulihan Ekosistem ini tentu saja menimbulkan persepsi yang berbeda-beda diantara para petani. Persepsi berkaitan dengan pemahaman petani terhadap program. Lebih lanjut (Mamuko, dkk., 2016) menyatakan bahwa persepsi adalah proses memahami lingkungan yang melibatkan pengorganisasian dan penafsiran sebagai rangsangan dalam suatu pengalaman psikologis. Persepsi dan karakteristik ini nantinya yang akan mendorong tingkat partisipasi masyarakat dalam kegiatan Pemulihan Ekosistem.

Berdasarkan masalah tersebut di atas maka dilakukan penelitian mengenai Karakteristik dan Persepsi Masyarakat desa Wonoasri terhadap kegiatan Pemulihan Ekosistem TNMB.

\section{METODE PENELITIAN}

Penelitian dilakukan di Desa Wonoasri, Kecamatan Tempurejo, Kabupaten Jemberpada Bulan Januari-Februari 2016. Desa Wonoasri merupakan 1 dari 10 daerah penyangga TN. Meru Betiri.Dalam sistem 
pengelolaan TNMB, Desa Wonoasri berada dalam wilayah kerja Resort Wonoasri, SPTN Wilayah II Ambulu. Lokasi penelitian dapat dilihat pada Gambar 1.

Metode yang digunakan dalam penelitian ini adalah metode deskriptif. Teknik penelitian adalah survey dimana teknik pengambilan sampel dilakukan secara acak terhadap 34 petani KETANMERAH. Data dukung dan latar belakang analisa diperkuat dengan dokumen dan studi pustaka yang terkait dengan permasalahan yang dibahas. Data yang telah terkumpul selanjutnya dilakukan analisis secara deskriptif. Analisis persepsi masyarakat terhadap program pemulihan ekosistem dilakukan dengan pendekatan kuantitatif dengan menggunakan Skala Likert.

\section{HASIL DAN PEMBAHASAN}

\section{Gambaran Umum Wilayah Penelitian}

Secara geografis Desa Wonoasri terletak $8^{\circ} 22^{\prime} 56^{\prime \prime}$ - $8^{\circ} 23^{\prime} 07^{\prime \prime}$ LS dan 113 $40^{\circ} 23^{\prime \prime}$ $-113^{\circ} 41^{\prime} 20^{\prime \prime}$ BT. Secara administratif pemerintahan, Desa Wonoasri masuk dalam wilayah Kecamatan Tempurejo,
Kabupaten Jember. Luas wilayah Desa Wonoasri adalah $624,547 \mathrm{Ha}$ yang terdiri dari 2 (dua) dusun yakni: Dusun Kraton dan Dusun Curah lele. Desa Wonoasri berbatasan dengan Desa Sidodadi (sebelah utara) dan Desa Curahnongko (Sebelah Selatan, Barat dan Timur).

Berdasarkan data tahun 2015 jumlah penduduk Desa Wonoasri rata-rata berjumlah 9,545 jiwa yang terdiri: laki-laki 4,802 jiwa dan perempuan 4,743 jiwa. Dengan rasio jenis kelamin 101,24 (Badan Pusat Statistik Jember, 2015). Penduduk Desa Wonoasri dominan adalah suku Jawa $(80 \%)$.

\section{Kondisi Sosial, Ekonomi dan Budaya Karakteristik Responden}

Responden peserta kegiatan Pemulihan Ekosistem di desa Wonoasri rata-rata adalah usia produktif yaitu: 25-45 tahun $(41,18 \%)$; dengan pekerjaan tetap didominasi pertanian; pendidikan rata-rata SD dan SMP dengan tanggungan keluarga rata-rata 1-3 orang. Responden yang diwawancarai adalah dari masyarakat biasa, ketua dan anggota kelompok tani mitra rehabilitasi. Secara lebih jelas dapat dilihat

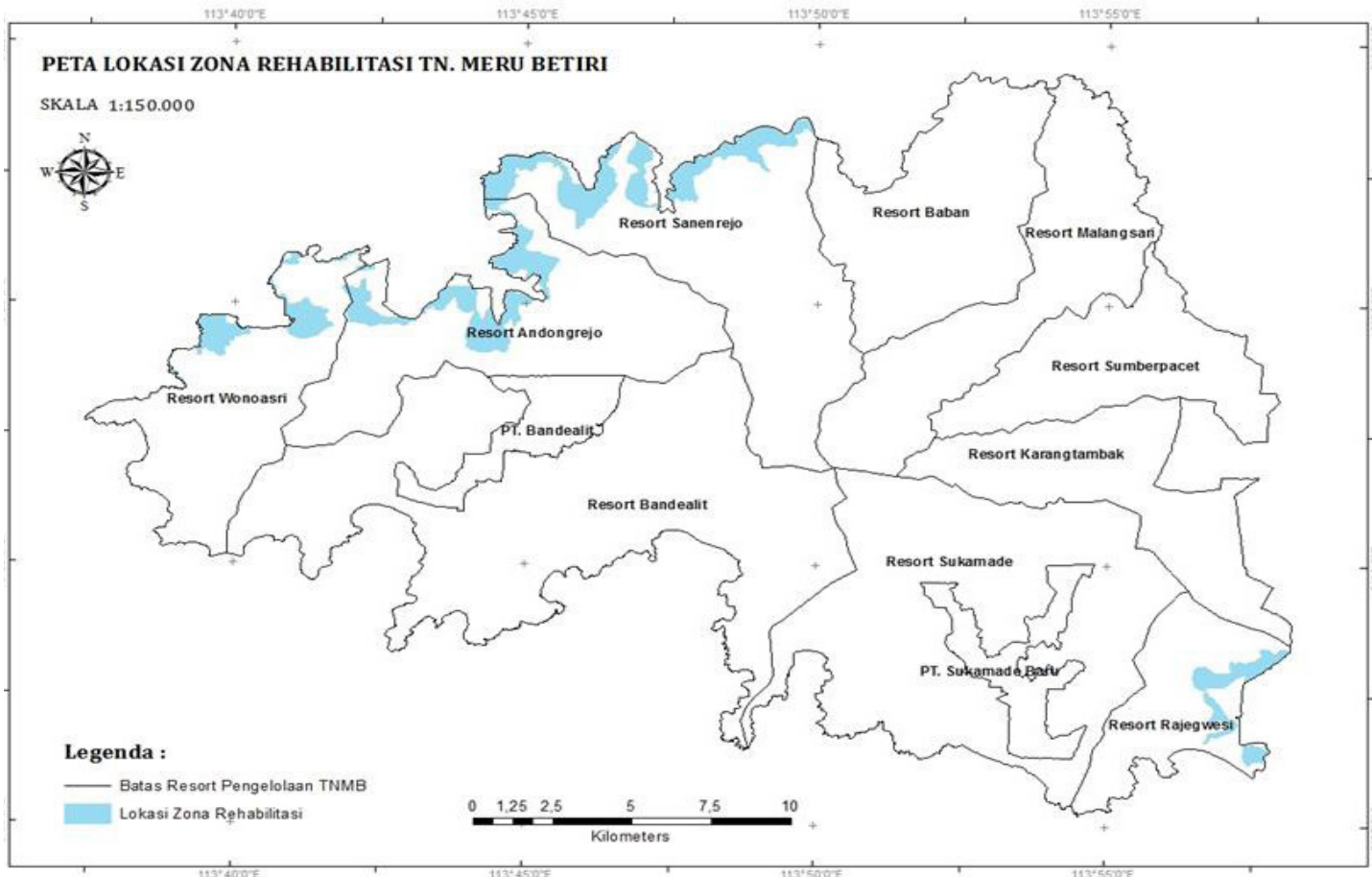

Sumber: Sulistiyowati, dkk., 2016

Gambar 1

Lokasi Penelitian di Resort Wonoasri 
Tabel 1

Karakteristik Responden Desa Wonoasri (Umur dan Pekerjaan Tetap)

\begin{tabular}{ccccccc}
\hline \multirow{2}{*}{ No } & \multicolumn{3}{c}{ Umur Responden (tahun) } & \multicolumn{3}{c}{ Jenis Pekerjaan } \\
\cline { 2 - 7 } & $25-45$ & $46-65$ & $66-85$ & Pertanian & Wiraswasta & Lain-lain \\
\hline 1. & $41,18 \%$ & $38,24 \%$ & $20,59 \%$ & $76,47 \%$ & $23,53 \%$ & $0 \%$ \\
\hline
\end{tabular}

Sumber: Data Primer Diolah, 2016

pada Tabel 1 dan Tabel 2.

Berdasarkan Tabel 1, nampak bahwa tenaga kerja usia produktif di Wonoasri tersedia dalam jumlah yang cukup banyak $(79,41 \%$ dari total responden). Diharapkan dengan semakin banyak petani berusia produktif akan dapat mendukung kegiatan Pemulihan Ekosistem TNMB. Lebih Ianjut (Adhawati, 1997) menyatakan bahwa umur merupakan salah satu identitas yang dapat mempengaruhi kemampuan kerja dan pola pikir.

Berdasarkan Tabel 2, terlihat pendidikan rata-rata dari responden adalah berpendidikan SD sampai SMP, meskipun ada beberapa yang berpendidikan SMA. Dengan rata-rata pendidikan yang relatif masih rendah tersebut tentunya kemampuan dalam penguasaan dan penerapan teknologi juga terbatas (Andri, 2014). Ditambahkan oleh (Mamuko, dkk., 2016), bahwa tingkat pendidikan petani berpengaruh pada kemampuan untuk mendapatkan dan menggunakan informasi yang berhubungan dengan rehabilitasi hutan dan lahan dalam aktifitas usahataninya.

Rata-rata responden memiliki jumlah tanggungan keluarga antara 1-3 orang yakni sebanyak 20 orang atau sekitar $58,82 \%$ dari total responden. Anggota keluarga dapat dimanfaatkan sebagai tenaga kerja dalam kegiatan Pemulihan Ekosistem TNMB sehingga dapat menghasilkan hasil yang lebih baik (Purwanti, 2007).

\section{Kepemilikan Iahan}

Luas penguasaan lahan baik lahan sawah maupun lahan kering sebagai gambaran potensi aset rumah tangga tani dan sebagai indikator sosial ekonomi yang penting bagi masyarakat pedesan. Rata-rata besarnya luasan lahan petani dan kepemilikan lahan lain dapat dilihat pada Tabel 3.

Sebagian responden memiliki luas lahan rehabilitasi: 0,25-0,5 $\mathrm{Ha}(89,29 \%)$. Indikasi ini memberikan gambaran bahwa potensi atau ketersediaan lahan garapan masih cukup luas. Dengan cukup luas lahan garapan petani maka petani tidak perlu lagi membuka areal hutan untuk dijadikan sebagai lahan usaha tani. Asalkan lahan dikelola secara tepat, maka lahan akan meningkatkan pendapatan petani (Purwanti, 2007).

Dari Tabel 3, diketahui juga bahwa sebagian besar peserta pemulihan ekosistem di Resort Wonoasri tidak memiliki lahan garap lainselain di rehabilitasi. Hal inilah yang menyebabkan tingkat ketergantungan responden terutama petani lahan rehabilitasi terhadap TN Meru Betiri termasuk tinggi (Sulistiyowati, dkk., 2016).

\section{Keterlibatan dalam Kegiatan Pemulihan Ekosistem dan Asal Kepemilikan Lahan Pemulihan Ekosistem}

Sebagian besar petani yang akan melakukan kegiatan Pemulihan Ekosistem merupakan petani rehabilitasi pada awal Program rehabilitasi $(67,65 \%)$ dan sebagian besar peserta pemulihan ekosistem di Re-

Tabel 2

Karakteristik Responden Desa Wonoasri (Tingkat Pendidikan dan Tanggungan Keluarga)

\begin{tabular}{cccccccc}
\hline \multirow{2}{*}{ No } & \multicolumn{3}{c}{ Pendidikan Responden } & \multicolumn{3}{c}{ Tanggungan keluarga (orang) } \\
\cline { 2 - 8 } & Tidak Tamat SD & SD & SMP & SMA & $1-3$ & $4-6$ & $7-9$ \\
\hline 1. & $14,71 \%$ & $44,12 \%$ & $35,29 \%$ & $5,88 \%$ & $58,82 \%$ & $38,24 \%$ & $2,94 \%$ \\
\hline Sumber: Data Primer Diolah, 2016 & & & & &
\end{tabular}


Tabel 3

Karakteristik Responden desa Wonoasri (Luas lahan dan Kepemilikan Lahan)

\begin{tabular}{ccccccc}
\hline \multirow{2}{*}{ No } & \multicolumn{4}{c}{ Luas Lahan $(\mathrm{Ha})$} & \multicolumn{2}{c}{ Kepemilikan lahan lain } \\
\cline { 2 - 6 } & $<0,25$ & $0,25-0,5$ & $0,51-0,75$ & $0,76-1$ & Ada & Tidak Punya \\
\hline 1. & $2,94 \%$ & $85,29 \%$ & $8,82 \%$ & $2,94 \%$ & $29,41 \%$ & $70,59 \%$ \\
\hline
\end{tabular}

sort Wonoasri mendapatkan lahannya dari membeli Tabel 4.

Berdasarkan Tabel 4, diketahui bahwa salah satu point penting dari pelaksana kegiatan Pemulihan Ekosistem di Resort Wonoasri adalah lamanya responden mengikuti kegiatan Pemulihan Ekosistem. Semakin lama responden menjadi peserta maka responden sudah mengetahui faktor-faktor yang berdampak pada kurang optimalnya keberhasilan kegiatan Pemulihan Ekosistem. Sehingga ke depan, peserta pemulihan ekosistem desa Wonoasri memiliki solusi yang tepat untuk peningkatan jumlah dan jenis tanaman pokok. Lebih Lanjut Akmal (2011) dalam (Widiarti, 2013) , menyatakan bahwa sistem yang tepat untuk Kegiatan Pemulihan Ekosistem yang melibatkan partisipasi masyarakat adalah sistem wanatani/agroforestri dimana sistem ini mengkombinasikan pohon hutan (untuk penahan air hujan) dan Jenis Pohon Serba Guna (JPSG) untuk menyediakan kecukupan pangan bagi masyarakat sekitar. Dengan demikian diharapkan hutan tidak akan diganggu lagi dan memiliki keragaman hayati yang tinggi dan tutupan vegetasi yang optimal, sehingga proses fungsi hutan dapat berlangsung normal.

Tantangan pelaksanaan Kegiatan Pemulihan Ekosistem di Resort Wonoasri ke depan adalah asal kepemilikan lahan garap. Dari hasil kuisioner diketahui bahwa 16 Responden $(47,06 \%)$ mendapatkan hak garap di lahan rehabilitasi dengan cara membeli/mengganti dari orang lain. Padahal di dalam Kesepakatan Kerjasama
Pengelolaan Kawasan di Zona Rehabilitasi Taman Nasional Meru Betiri tidak diperkenankan melakukan jual beli lahan. Lahan garap yang tidak mampu dikerjakan seharusnya diserahkan kembali ke TNMB. Ada 2 (dua) kemungkinan penyebab masalah ini terjadi yakni: 1) kebutuhan ekonomi yang mendesak dan 2) keinginan untuk memperluas lahan rehabilitasi.

Beberapa alternatif penyelesaian masalah tersebut di atas adalah dengan 1) memperbaharui Kesepakatan Kerjasama Pengelolaan Kawasan di Zona Rehabilitasi yang telah berakhir sejak tahun 2007 menjadi Perjanjian Kerjasama dengan mencantumkan hak dan kewajiban secara jelas, jangka waktu pelaksanaan dan konsekuensi jika tidak memenuhi persyaratan dari TNMB, 2) melakukan pertemuan rutin kelompok tani mitra rehabilitasi dalam rangka memperkuat kelembagaan kelompok, 3) melakukan patroli perlindungan di lahan rehabilitasi yang rawan perambahan. Perjanjian Kerjasama (PKS) Pemulihan Ekosistem TNMB merupakan prasyarat awal pelaksanaan kegiatan $\mathrm{Pe}$ mulihan Ekosistem dilakukan.

\section{Pendapatan Keluarga}

Pendapatan keluarga di desa Wonoasri pada umumnya diperoleh dari usaha tani dan luar usaha tani. Usaha tani diperoleh dari lahan tegal, sawah, pekarangan, hutan. Pendapatan ini sudah dapat memenuhi kebutuhan hidup layak petani, dimana kebutuhan hidup layak di Kabupaten Jember adalah Rp. 1.629.000,-I

Tabel 4

Karakteristik Responden Desa Wonoasri (Tahun dan Asal Kepemilikan Lahan)

\begin{tabular}{ccccccc}
\hline \multirow{2}{*}{ No } & \multicolumn{3}{c}{ Tahun } & \multicolumn{3}{c}{ Asal lahan PE } \\
\cline { 2 - 7 } & $1994-2004$ & $2005-2010$ & $2011-2016$ & Mencari & Membeli & Lainnya \\
\hline 1. & $67,65 \%$ & $17,65 \%$ & $14,71 \%$ & $44,12 \%$ & $47,06 \%$ & $8,82 \%$ \\
\hline
\end{tabular}

Sumber: Data Primer Diolah, 2016 
Tabel 6

Rata-rata Pendapatan Keluarga di Desa Wonoasri

\begin{tabular}{rcrrrr}
\hline \multicolumn{2}{c}{ Rata-rata Pendapatan/bln } & \multicolumn{2}{c}{ Rata-rataPengeluaran/bln } & $\begin{array}{c}\text { Rata-rata } \\
\text { Pendapatan } \\
\text { bersih/bln }\end{array}$ & $\begin{array}{c}\text { Rata-rata } \\
\text { Pengeluaran } \\
\text { bersih/bln }\end{array}$ \\
\hline 955,735 & $1.266,176$ & 698,824 & $1.131,294$ & $2.221,912$ & 1.830 .118 \\
\hline
\end{tabular}

Sumber: Data Primer Diolah, 2016

bulan/KK(Gubernur Jawa Timur, 2015). Ditambahkan oleh (Sulistiyowati, dkk., 2016) bahwa pendapatan keluarga petani di desa Wonoasri menurut hasil kalender musim bekisar antara Rp. 1.000.000,00 per bulan sampai Rp. 11.300.000,00 per bulan dengan rata-rata Rp. 4.995.455,-Selengkapnya data pendapatan keluarga di desa Wonoasri dapat dilihat pada Tabel 6.

Pendapatan dari TN diperoleh dari hasil tanaman semusim berupa :pisang, padi, jagung, kacang dan tanaman Peje (Purpurea javanica). Padi dan jagung ditanam sekali dalam musim tanam.Tanaman Peje dipanen sekali dalam 1 tahun. Hasil panen padi lebih banyak dikonsumsi sendiri sedang pisang, jagung dan Peje dijual. Selain tanaman semusim, tanaman pokok yang sudah berbuah adalah: nangka, kedawung dan mengkudu. Ditambahkan oleh (Sulistiyowati, dkk., 2016), bahwa tingginya pendapatan dari hasil lahan rehabilitasi ini menunjukkan bahwa eksistensi kawasan TNMB memberikan manfaat penting terutama karena memberikan kontribusi tinggi terhadap pendapatan masyarakat sekitar TNMB.Untuk penjualan hasil tanaman rehabilitasi (tanaman semusim/tanaman pokok), sebagian besar petani masih mengandalkan pengepul $(50 \%)$. Ketergantungan ini yang menyebabkan harga hasil tanaman semusim/ tanaman pokok di bawah harga pasaran.

Persepsi Petani Mitra Rehabilitasi Terkait Kegiatan Pemulihan Ekosistem Analisis persepsi petani KETANMERAH terhadap kegiatan pemulihan ekosistem di TNMB dilakukan dengan menggunakan metode skala Likert.Skala Likert digunakan dengan skala 1 (rendah), 2 (sedang) dan 3 (tinggi). Pengukuran persepsi dijabarkan konsep pengetahuan (kognitif) dan sikap (afektif) dalam konteks pengetahuan tentang kegiatan Pemulihan Ekosistem, Jumlah tanaman pokok yang dipersyaratkan, kesediaan membibitkan sendiri dan kesediaan meninggalkan lahan. Hasil rekapitulasi nilai persepsi setiap responden selanjutnya dibuat kategori, dimana nilai tertinggi adalah 68 dan nilai terendah 0 .Hasil pengurangan antara skor tertinggi dan terendah tersebut dibagi dalam tiga kelas dengan rentang nilai masing masing dengan menggunakan persamaan di atas. Berdasarkan persamaan tersebut diperoleh kategori tingkat persepsi sebagai berikut: persepsi tinggi dengan rentang 66,8-100, tingkat persepsi sedang dengan rentang nilai 33.4-66,7 dan tingkat persepsi rendah dengan nilai 0-33.3.Selengkapnya hasil analisis persepsi adalah sebagaimana tersaji pada Tabel 7 .

\section{Pengetahuan tentang Kegiatan Pemuli- han Ekosistem}

Berdasarkan Tabel 8, diketahui bahwa persepsi petani KETANMERAH terkait pengetahuan tentang kegiatan Pemulihan Ekosistem TNMB adalah tinggi. Mereka sudah mengetahui hak dan kewajiban sebagai peserta rehabilitasi. Sumber informasi responden sebagian besar berasal dari Petugas, Pemerintahan Desa dan Kelompok Tani Mitra Rehabilitasi. Lebih lanjut (Watemin \& Budiningsih, 2015), menyatakan bahwa fungsi dari kelompok tani diantaranya adalah untuk memperoleh informasi yang terkait dengan permasalahan pertanian atau informasi mengenai teknologi baru di bidang pertanian.

31 dari 34 Responden (91,18\%) menyatakan bahwa dirinya mengetahui Kelompok Tani Mitra Rehabilitasinya hal ini dikarenakan sejak zona rehabilitasi ditetapkan dan pengelolaannya melibat- 
Tabel 7

Persepsi Petani KETANMERAH akan Kegiatan Pemulihan Ekosistem di Desa Wonoasri

\begin{tabular}{clcc}
\hline No & \multicolumn{1}{c}{ Tema Persepsi } & Skoring & Ket \\
\hline 1. & Pengetahuan & 67,65 & tinggi \\
2. & $\begin{array}{l}\text { Jumlah tanaman pokok yang } \\
\text { dipersyaratkan }\end{array}$ & 52,94 & sedang \\
3. & $\begin{array}{l}\text { Kesediaan melakukan pembibitan } \\
\text { mandiri }\end{array}$ & 69,12 & tinggi \\
4. & Kesediaan meninggalkan lahan & 57,35 & sedang \\
\hline
\end{tabular}

Sumber: Data Primer Diolah, 2016

kan masyarakat setempat, sejak itu pula kelompok tani mulai terbentuk. Lebih lanjut (Sinaga, 2013) menyatakan bahwa kelompok tani merupakan gabungan beberapa warga yang mendapatkan hak untuk menanami lahan di lokasi tertentu di lahan rehabilitasi yang berbeda. Kelompok tani ini disatukan berdasarkan kedekatan tempat tinggal dan lahan garapan. Terbentuknya Kelompok memudahkan dalam pengelolaan areal pemulihan ekosistem dikarenakan masing-masing kelompok mempunyai acara pertemuan.

\section{Jumlah Tanaman Pokok yang Diper- syaratkan}

Persepsi petani KETANMERAH terkait jumlah tanaman pokok yang dipersyaratkan menunjukkan hasil sedang. Meski pemahaman terkait program sudah baik namun jumlah dan jenis tanaman pokok di lahan rehabilitasi TNMB sebagian besar belum memenuhi persyaratan $(1 \mathrm{Ha}$ minimal 500 batang dengan 40 jenis tanaman pokok). Beberapa penyebab belum terpenuhinya persyaratan jumlah tanaman pokok oleh petani diantaranya: (1) petani lebih mengutamakan tanaman semusim, (2) faktor cuaca/musim dan (3) kesuburan tanah di lahan rehabilitasi semakin menurun.

Di dalam Kesepakatan Kerjasama Antara Balai TN. Meru Betiri dengan Petani Mitra Rehabilitasi menyebutkan bahwa selama tanaman pokok belum berbuah maka petani rehabilitasi dapat menanam tanaman semusim untuk menambah penghasilan. Tanaman semusim lebih diperhatikan mengingat proses penanaman hingga panen membutuhkan waktu yang tidak terlalu lama dan dapat menambah penghasil petani KETANMERAH. Jenis tanaman semusim yang sering ditanam adalah: Padi, Kacang Hijau, Jagung, Cabai, Ketela rambat, kacang panjang dan peje. Kebanyakan tanaman semusimditanam di sela-sela tanaman pokok dan dipanen pada saat akhir musim kemarau. Beberapa jenis tanaman semusim yang dipanen pada bulan Juli-Agustus adalah: jagung, peje. Seluruh responden telah melakukan rotasi tanaman dengan tetap memperhatikan musim untuk jenis tanaman semusim yang akan ditanam.

Anomali musim juga berpengaruh terhadap jumlah bibit tanaman pokok yang mati setelah ditanam. Selain itu faktor kesuburan tanah juga berpengaruh terhadap jumlah tanaman pokok. Lebih lanjut (Sulistiyowati, dkk., 2016) menyatakan bahwa hasil analisis contoh sampel lahan rehabilitasi di Wonoasri menunjukkan kadar bahan organik tanah yang sangat rendah $(0,796-$ 0,964\%). Padahal N-total, P-tersedia dan K-tersedia tanah merupakan unsur hara esensial tanaman dimana jika jumlahnya kurang akan mengganggu pertumbuhan tanaman bahkan bisa mati.

Tanaman pokok yang ditanam dalam kegiatan Pemulihan TNMB merupakan jenis asli dari kawasan TNMB, bernilai ekonomis penting dan dimanfaatkan buahnya (bukan kayu). Pada tahun 1999, TNMB telah memberikan rekomendasi 40 jenis tanaman pokok yang dapat ditanam di lahan rehabilitasi. Dari hasil pendataan responden diketahui bahwa hanya 5 dari 40 jenis tanaman pokok yang dominan 
ditanam oleh petani rehabilitasi di desa Wonoasri. Selengkapnya jenis tanaman pokok terdapat pada Tabel 8.

Berdasarkan Tabel 8, di atas diketahui bahwa jenis nangka memiliki persentase jumlah tanaman pokok tertinggi di lahan rehabilitasi Desa Wonoasri. Hasil ini sejalan dengan penelitian dari (Sulistiyowati, dkk., 2016) yang menyebutkan bahwa jenis Nangka merupakan jenis yang paling dominan di lahan rehabilitasi TNMB selain jenis Petai, Kedawung dan Mengkudu. Lebih lanjut (Sulistiyowati, dkk., 2016), mengatakan bahwa masih sedikitnya jenis tanaman pokok yang ditanam di lahan rehabilitasi dikarenakan petani memilih jenis tanaman pokok yang memiliki nilai ekonomi tinggi seperti: kedawung, petai, nangka, mengkudu, dan durian. Sedikitnya terdapat 12 jenis tanaman pokok yang telah berbuah yakni: petai, nangka, mangga, kemiri, kluwih, alpukat, pakem, durian, sirsak, sukun, mengkudu, melinjo. Sebagian besar tanaman pokok dapat dipanen pada bulan Nopember antara lain: nangka, keluwih, alpukat, durian, mengkudu dan melinjo. Jenis tanaman pokok yang dapat panen sepanjang tahun adalah mengkudu namun tidak menguntungkan petani karena tidak diminati pasar di daerah tersebut.

Spesies tanaman pokok yang terdapat di lahan pemulihan ekosistem tidak semua ada di lahan rehabilitasi setiap petani responden. Dari hasil pengamatan langsung di lapangan diketahui jika sebagian besar responden telah menanam jumlah tanaman pokok $>40$ batang tanaman di masing-masing luasan lahan. Hanya sebagian kecil yang menanam dalam jumlah yang sedikit. Hal ini menunjukkan tingkat partisipasi masyarakat desa Wonoasri dalam kegiatan Pemulihan Ekosistem TNMB sangat besar.

Dari 5 (lima) jenis tanaman pokok yang dominan di Resort Wonoasri diketahui hanya 1 (satu) spesies yang merupakan tanaman kehutanan yakni Kedawung sedang 4 (empat) jenis lainnya merupakan tanaman buah. Oleh karenanya dalam pengkayaan jenis tanaman pokok perlu ditambahkan spesies tanaman kehutanan. Hal ini dilakukan agar konsep agroforestri berjalan seperti seharusnya. Selain hal tersebut di atas adalah perlunya pengkayaan spesies asli TNMB diantaranya: kedawung, kepuh, kemiri, pinang, joho lawe Karena spesies asli TNMB lebih sedikit ditanam dibandingkan spesies eksotik. Jenis tanaman obat juga direkomendasikan di tanam di lahan rehabilitasi diantaranya: cabai jawa, pule pandak, pulai, kapulaga, aren, langsat, suren, kemukus, iles-iles.

\section{Kesediaan Melakukan Pembibitan}

Kesediaan melakukan pembibitan sendiri memberikan penilaian persepsi yang tinggi $47,06 \%$ persen responden menyatakan kesediaannya dalam melakukan pembibitan sendiri. Di awal kegiatan Rehabilitasi (tahun 1999), jenis pembibitan tanaman pokok dilakukan oleh petani rehabilitasi secara mandiri. Di tahun-tahun selanjutnya kegiatan petani rehabilitasi selalu mendapatkan bantuan jenis tanaman pokok dari TNMB/BPDAS Sampean. Beberapa kendala yang dihadapi responden dalam pembibitan secara swadaya diantaranya keahlian dalam pembibitan jenis asli TNMB serta

Tabel 8

Jenis-jenis Tanaman Pokok di Lahan Rehabiliasi Desa Wonoasri

\begin{tabular}{|c|c|c|}
\hline No & Jenis tanaman pokok & $\%$ \\
\hline 1. & Nangka & 44,12 \\
\hline 2. & Kedawung & 23,52 \\
\hline 3. & Petai & 23,52 \\
\hline 4. & Mengkudu & 5,88 \\
\hline 5. & Mangga & 2,94 \\
\hline
\end{tabular}


biaya pembuatan bibit yang tidak sedikit. Ke depan perlu upaya untuk mendorong petani KETANMERAH melakukan pembibitan secara swadaya dengan jenis-jenis tanaman asli kehutanan.

\section{Kesediaan Meninggalkan Lahan}

Persepsi petani KETANMERAH terkait kesedian meninggalkan lahan adalah sedang. Sebagian besar petani rehabilitasi tidak bersedia meninggalkan lahan rehabilitasi di akhir perjanjian Kerjasama meskipun tidak memenuhi jumlah tanaman pokok yang dipersyaratkan oleh TNMB. Penyebab utama adalah $70,69 \%$ petani KETANMERAH desa Wonoasri tidak memiliki lahan pertanian selain lahan rehabilitasi. Berbeda halnya dengan petani KETANMERAH yang memiliki lahan di luar lahan rehabilitasi, mereka bersedia meninggalkan lahan rehabilitasi karena menyadari jika lahan yang mereka garap bukan hak miliknya.

Untuk memperjelas status penggunaan lahan di TNMB maka Perjanjian Kerjasama (PKS) Antara Balai Taman Nasional Meru Betiri dan Petani Rehabilitasi perlu secepatnya dilakukan. Dengan adanya PKS ini maka petani yang sudah habis masa perjanjiannya dan belum memenuhi persyaratan yang telah ditetapkan oleh TNMB maka harus dikeluarkan. Diperlukan adanya ketegasan Petugas TNMB dalam mengawal PKS ini sehingga reward/punishment bagi peserta pemulihan ekosistem TNMB dapat dijalankan. Selain itu perlu ditingkatkan pendekatan Petugas lapang kepada petani KETANMERAH untuk memotivasi dan meningkatkan peran serta mereka dalam kegiatan Pemulihan Ekosistem dengan meningkatkan jumlah dan jenis tanaman pokok yang dipersyaratkan oleh TNMB.

\section{SIMPULAN}

Karakteristik masyarakat Wonoasri pada umumnya adalah petani dengan umur produktif serta sudah paham akan manfaat dan dampak kegiatan Pemulihan Ekosistem. Sebagian besar petani memiliki luas lahan rehabilitasi sebesar $0,25 \mathrm{Ha}$ dan ditanami dengan pola agroforestri sederhana (tanaman pokok dengan satu atau beberapa tanaman musiman).Pendapatan keluarga di desa Wonoasri sudah berada diatas Kebutuhan Hidup Layak Kab. Jember namun demikian masih diperlukan penguatan kapasitas kelembagaan kelompok, pembinaan yang lebih baik dan terstruktur serta monitoring dan evaluasi secara berkelanjutan untuk meningkatkan persentase jumlah dan jenis tanaman pokok. Persepsi petani KETANMERAH yang memberikan nilai tinggi adalah terkait pengetahuan kegiatan Pemulihan Ekosistem TNMB serta kesediaan petani untuk melakukan pembibitan sendiri. Ke depan dalam rangka mendukung keberhasilan pemulihan ekosistem TNMB hendaknya diprioritaskan spesies tanaman kehutanan dan jenis asli TNMB dan tanaman obat. Jumlah tanaman pokok yang dipersyaratkan dan kesediaan meninggalkan lahan memberikan hasil persepsi dengan kategori sedang. Meskipun memberikan penambahan penghasilan petani KETANMERAH, mereka utamanya masih mengutamakan tanaman semusim. Petani yang tidak memiliki lahan garap di luar rehabilitasi memiliki ketergantungan yang sangat tinggi terhadap TNMB sehingga Perjanjian Kerjasama dapat berfungsi sebagai kartu kontrol keseriusan mereka mengikuti kegiatan Pemulihan Ekosistem TNMB. Kedepan, diperlukan adanya dukungan dan kerjasama dari Perguruan Tinggi, Pemkab Jember, BUMN dan LSMutamanya dalam hal peningkatan kualitas produk hasil kegiatan Pemulihan Ekosistem (pengolahan, pengemasan dan pemasaran produk) sehingga dengan cara kerja yang terencana dan sistematis ini dapat menjadikan masyarakat lebih mandiri dan tidak tergantung kawasan hutan.

\section{UCAPAN TERIMA KASIH}

Kegiatan Penelitian ini dapat terlaksana berkat dukungan dari DIPA KSDAE Balai TN. Meru Betiri. 


\section{DAFTAR PUSTAKA}

Adhawati, S. S. 1997. Analisis Ekonomi Pemanfaatan lahan Pertanian Dataran Tinggi di Desa Parigi (Hulu DAS Malino) Kabupaten Gowa. Universitas Hasanuddin Makassar.

Amzu, E. (2007). Sikap Masyarakat dan Konservasi Suatu Analisis Kedawung (Parkia timoriana (DC) Merr) Sebagai Stimulus Tumbuhan Obat Bagi Masyarakat, Kasus di Taman Nasional Meru Betiri. Institut Pertanian Bogor.

Andri, Kuntoro Boga. 2014. Profil dan Karakter Sosial Ekonomi Petani Tanaman Pangan di Bojonegoro. Agriekonomika 3(2): 167-179.

Badan Pusat Statistik Jember. 2015. Statistik Kecamatan Tempurejo 2015. Jember.

Foresta, D., \& Michon G. 1997. The Agroforest Alternative To Imperata Grasslands: When Smallholder Agriculture and Forestry Reach Sutainability. Agroforestry System 36: 105-120.

Gubernur Jawa Timur. 2015. Peraturan Gubernur Jawa Timur Nomor 68 Tahun 2015 tentang Upah Minimum Kabupaten/Kota di Jawa Timur Tahun 2016.

Mamuko, F., Walangitan, H., \& Tilaar, W. 2016. Persepsi dan Partisipasi Masyarakat dalam Upaya Rehabilitasi Hutan dan Lahan di Kabupaten Bolaang Mongondow Timur. Eugenia 22(2): 80-92.

Meru Betiri. (2007). Kesepakatan Kerjasama Antara Balai Taman Nasional Meru Betiri dengan Kelompok Tani Bonangan Tentang Pengelolaan Kawasan di Zona Rehabilitasi Taman Nasional Meru Betiri. Jember.

Purwanti, R. 2007. Pendapatan Petani Dataran Tinggi Sub DAS Malino (Studi
Kasus: Kelurahan Gantarang, Kabupaten Gowa). Penelitian Sosial Dan Ekonomi Kehutanan 4(3): 257-269.

Sinaga, S. M. 2013. Manfaat Agroforestri Bagi Masyarakat di Zona Rehabilitasi Taman Nasional Meru Betiri. Institut Pertanian Bogor.

Sulistiyowati, H., Winarso, S., Suciati, L. P., Guntoro, D. A., \& Atmojo, N. D. 2016. Kajian Pra Pemulihan Ekosistem TN. Meru Betiri.

Watemin, \& Budiningsih, S. 2015. Pemberdayaan Petani Melalui Penguatan Modal Kelembagaan Petani di Kawasan Agropolitan Kecamatan Belik Kabupaten Pemalang. Agriekonomika 4(1): 50-58.

Widiarti, A. 2013. Pemulihan Hutan Dengan Partisipasi Masyarakat (Forest Recovery with Community Participation). Penelitian Hutan dan Konservasi Alam 20(2): 215-228. 